\title{
Design Option of Heat Exchanger for the Next Generation Nuclear Plant
}

\author{
$4^{\text {th }}$ International Topical Meeting on \\ High Temperature Reactor Technology
}

\author{
Chang H. Oh \\ Eung S. Kim
}

September 2008

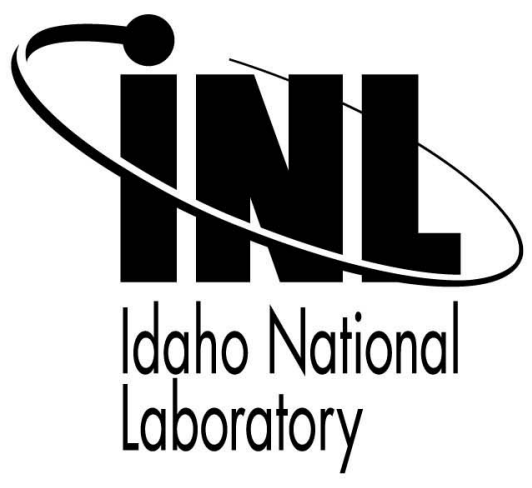

This is a preprint of a paper intended for publication in a journal or proceedings. Since changes may be made before publication, this preprint should not be cited or reproduced without permission of the author. This document was prepared as an account of work sponsored by an agency of the United States Government. Neither the United States Government nor any agency thereof, or any of their employees, makes any warranty, expressed or implied, or assumes any legal liability or responsibility for any third party's use, or the results of such use, of any information, apparatus, product or process disclosed in this report, or represents that its use by such third party would not infringe privately owned rights. The views expressed in this paper are not necessarily those of the United States Government or the sponsoring agency. 


\section{DESIGN OPTION OF HEAT EXCHANGER FOR THE NEXT GENERATION NUCLEAR PLANT}

\author{
Chang H. Oh \\ Idaho National Laboratory \\ P.O. Box 1625 \\ Idaho Falls, Id. 83415
}

\author{
Eung S. Kim \\ Idaho National Laboratory \\ P.O. Box 1625 \\ Idaho Falls, Id. 83415
}

\begin{abstract}
The Next Generation Nuclear Plant (NGNP), a very High temperature Gas-Cooled Reactor (VHTR) concept, will provide the first demonstration of a closed-loop Brayton cycle at a commercial scale, producing a few hundred megawatts of power in the form of electricity and hydrogen. The power conversion unit (PCU) for the NGNP will take advantage of the significantly higher reactor outlet temperatures of the VHTRs to provide higher efficiencies than can be achieved with the current generation of light water reactors. Besides demonstrating a system design that can be used directly for subsequent commercial deployment, the NGNP will demonstrate key technology elements that can be used in subsequent advanced power conversion systems for other Generation IV reactors. In anticipation of the design, development and procurement of an advanced power conversion system for the NGNP, the system integration of the NGNP and hydrogen plant was initiated to identify the important design and technology options that must be considered in evaluating the performance of the proposed NGNP.
\end{abstract}

As part of the system integration of the VHTRs and the hydrogen production plant, the intermediate heat exchanger is used to transfer the process heat from VHTRs to the hydrogen plant. Therefore, the design and configuration of the intermediate heat exchanger is very important. This paper will include analysis of one stage versus two stage heat exchanger design configurations and simple stress analyses of a printed circuit heat exchanger (PCHE), helical coil heat exchanger, and shell/tube heat exchanger.

\section{INTRODUCTION}

An intermediate heat exchanger (IHX) is one of the essential components in the VHTR systems since it transfers reactor core heat to the other systems for the application of electricity generation or hydrogen production. Therefore, its effectiveness is directly related to the overall system efficiency and economics. Generally, the VHTR systems use gas coolant having poor heat transfer capability that requires a very large size and heat transfer area. For this reason, a compact heat exchanger (CHE) with a large surface area density is recently being considered as a potential candidate for an IHX, replacing the classical shell and tube design. This type of heat exchanger is widely used in industry, especially for gas-to-gas or gas-toliquid heat exchange.

A compact heat exchanger is arbitrarily referred to be a heat exchanger with a surface area density greater than $700 \mathrm{~m}^{2} / \mathrm{m}^{3}[1]$. The compactness is usually achieved by fins and micro-channels, and leads to the enormous heat transfer enhancement and size reduction. The surface area density is the total heat transfer area divided by the volume of the heat exchanger. In the case of Printed Circuit Heat Exchangers (PCHEs) considered in this paper, the heat transfer surface area density can be as high as $2,500 \mathrm{~m}^{2} / \mathrm{m}^{3}[1,2]$. This high compactness implies an appreciable reduction in material cost. A major advantage of this heat exchanger is its ability to operate at high temperatures and under high pressure while standard shell-and-tube heat exchangers would require very careful material selection and still possibly have difficulties operating at these high pressures and temperatures. The PCHE units manufactured by Heatric ${ }^{\mathrm{TM}}$ allow operation at temperatures and pressures up to $900^{\circ} \mathrm{C}$ and $50 \mathrm{MPa}$, respectively. Figure 1 depicts a typical core of the PCHE. These heat exchangers are constructed from flat alloy plates with fluid flow passages photo-chemically etched into them. The plates are then staked and diffusion-bonded together to form strong, compact cores. 


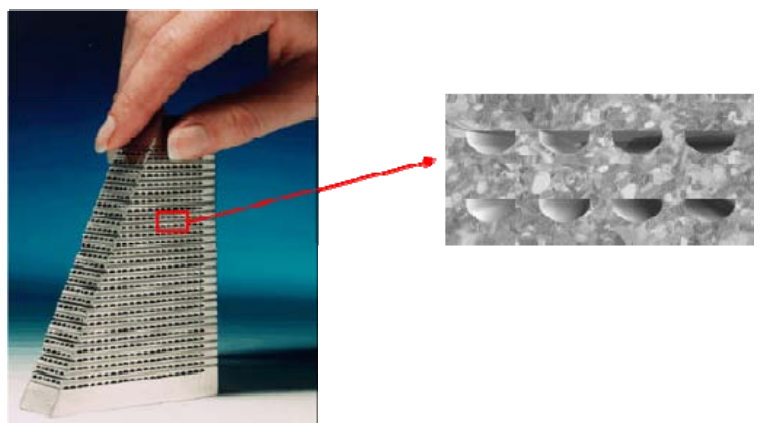

Figure 1. Cross-section through a typical PCHE core. (Courtesy of Heatric Ltd)

In this paper, two options of IHX arrangements were investigated; (1) single-stage, (2) two-stage [3]. A single-stage is the most common type of IHX arrangement. In this concept, one big IHX unit is connected to the reactor primary side and the secondary side to exchange heat between them. Sometimes, the size of the IHX is almost the same scale as the reactor vessel or power conversion units. In the two-stage concept, we split the IHX into two parts; low temperature and high temperature sections. The low temperature section is designed for the full lifetime, while the high temperature unit for replacement within plant lifetime. Maximum temperature of the low temperature section is around $760{ }^{\circ} \mathrm{C}$. This limit allows use of ASME Section III, Subsection NH materials such as Alloy $800 \mathrm{H}$. In the high temperature section, alloy 617,230 or ceramics are potential candidates.

In this paper, various options of IHXs were taken into consideration in terms of arrangement, materials and types. Finally, the options were compared together in view of thermal design and mechanical stress, and some suitable options for VHTR applications were recommended.

\section{THERMAL DESIGN METHODS}

In this section, thermal designs have been performed for three types of IHXs; shell-and-tube, PCHE and helical coil. Among them, the shell-and-tube heat exchanger is the most common heat exchanger type. This heat exchanger is built of round tubes mounted in a cylindrical shell with the tubes parallel to the shell. For design of shell-and-tube heat exchanger, we followed the general design guidelines provided by the heat transfer and heat exchanger handbooks [1, 4, and 5], Table 1 summarizes major parameters and guidelines used in this paper for thermal design of shell-and-tube heat exchangers.

For thermal design of PCHEs, we followed the general compact heat exchanger design procedure with the equations and parameters summarized by Hesselgreaves [2]. In the thermal design, the printed circuit heat exchangers are generally subjected to very few constraints compared to the shell-andtube heat exchanger. Fluids may be liquid, gas or two-phase. Multi-stream and multi-pass configurations can be assembled and flow arrangements can be truly counter-current, co-current, cross-flow, or a combination of these, at any required pressure drop.

Table 1. Guideline for shell-and-tube type heat exchanger design parameter change.

\begin{tabular}{|c|c|c|c|c|c|c|}
\hline $\begin{array}{c}\text { Adjusted } \\
\text { Parameters }\end{array}$ & $\begin{array}{c}\text { High } \\
\text { pressure } \\
\text { drop } \\
\text { shell side }\end{array}$ & $\begin{array}{c}\text { High } \\
\text { pressure } \\
\text { drop tube } \\
\text { side }\end{array}$ & $\begin{array}{c}\text { Low } \\
\text { coefficien } \\
\text { t Shell } \\
\text { side }\end{array}$ & $\begin{array}{l}\text { Low } \\
\text { coefficien } \\
\text { t tube } \\
\text { side }\end{array}$ & $\begin{array}{c}\text { Tempera } \\
\text { ture cross }\end{array}$ & $\begin{array}{c}\text { Vibration } \\
\text { indicatio } \\
\mathbf{n}\end{array}$ \\
\hline Baffle type & $\begin{array}{l}\text { Double } / \mathrm{Tr} \\
\text { iple } \\
\text { segmental }\end{array}$ & - & $\begin{array}{c}\text { Single } \\
\text { Segmenta } \\
1\end{array}$ & - & - & $\begin{array}{l}\text { Double/tri } \\
\text { ple } \\
\text { segmental }\end{array}$ \\
\hline Shell type & $\begin{array}{c}\mathrm{J} \text { or } \mathrm{X} \\
\text { type shell }\end{array}$ & - & $\begin{array}{c}E \text { or } F \\
\text { type shell }\end{array}$ & - & $\begin{array}{l}\text { E,F or G } \\
\text { type shell }\end{array}$ & $\begin{array}{c}\mathrm{J} \text { or } \mathrm{X} \\
\text { type shell }\end{array}$ \\
\hline $\begin{array}{c}\text { Tube } \\
\text { pattern }\end{array}$ & $\begin{array}{l}\text { Rotated } \\
\text { square or } \\
\text { square }\end{array}$ & - & $\begin{array}{c}\text { Triangula } \\
\mathrm{r}\end{array}$ & - & 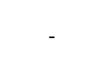 & $\begin{array}{l}\text { Rotated } \\
\text { Square }\end{array}$ \\
\hline $\begin{array}{c}\text { Tube } \\
\text { diameter }\end{array}$ & $\begin{array}{l}\text { Increase } \\
\text { to } 1 \text { " or } \\
1 / 25^{\prime \prime}\end{array}$ & $\begin{array}{l}\text { Increase } \\
\text { to } 1 \text { "' to } \\
1.25 \text { ", }\end{array}$ & $\begin{array}{l}\text { Decrease } \\
\text { to } 0.625^{\prime \prime} \\
\text { or } 0.5^{\prime \prime}\end{array}$ & $\begin{array}{l}\text { Decrease } \\
\text { to } 0.625^{\prime \prime} \\
\text { or } 0.5^{\prime \prime}\end{array}$ & - & $\begin{array}{l}\text { Increase } \\
\text { to } 1 \text { "'or } \\
1.25 \text { " }\end{array}$ \\
\hline Baffle cut & $\begin{array}{c}\text { Use } 30 \% \\
\text { to } 40 \%\end{array}$ & - & $\begin{array}{c}\text { Use } 15 \% \\
\text { to } 20 \%\end{array}$ & - & - & - \\
\hline Tube pitch & $\begin{array}{c}\text { Increase } \\
\text { to } 1.4 \text { or } \\
1.5 \mathrm{X} \text { tube } \\
\text { OD }\end{array}$ & - & $\begin{array}{l}\text { Limit to } \\
\text { TEMA } \\
\text { std } \\
\text { spacing }\end{array}$ & - & - & $\begin{array}{c}\text { Increase } \\
\text { to } 1.4 \text { or } \\
1.5 \mathrm{X} \text { tube } \\
\text { OD }\end{array}$ \\
\hline $\begin{array}{l}\text { Fluid } \\
\text { allocation }\end{array}$ & $\begin{array}{l}\text { Switch } \\
\text { sides }\end{array}$ & $\begin{array}{l}\text { Switch } \\
\text { sides }\end{array}$ & $\begin{array}{l}\text { Switch } \\
\text { sides }\end{array}$ & $\begin{array}{l}\text { Switch } \\
\text { sides }\end{array}$ & - & $\begin{array}{l}\text { Switch } \\
\text { sides }\end{array}$ \\
\hline $\begin{array}{c}\text { Arrangeme } \\
\text { nt }\end{array}$ & $\begin{array}{l}\text { Increase \# } \\
\text { of exch. } \\
\text { In parallel }\end{array}$ & $\begin{array}{l}\text { Increase \# } \\
\text { of exch. } \\
\text { In parallel }\end{array}$ & $\begin{array}{c}\text { Increase \# } \\
\text { of exch. } \\
\text { In series }\end{array}$ & - & $\begin{array}{c}\text { Increase \# } \\
\text { of exch. } \\
\text { In series }\end{array}$ & $\begin{array}{c}\text { Increase \# } \\
\text { of exch. } \\
\text { In parallel }\end{array}$ \\
\hline $\begin{array}{l}\text { \# Tube } \\
\text { passes }\end{array}$ & - & Plain & - & $\begin{array}{c}\text { Increase \# } \\
\text { of tube } \\
\text { passes }\end{array}$ & $\begin{array}{l}\text { Limit to } \\
\text { one tube } \\
\text { pass }\end{array}$ & - \\
\hline Tube type & Plain & & $\begin{array}{c}\text { Ext. } \\
\text { Enhanced }\end{array}$ & $\begin{array}{l}\text { Internally } \\
\text { enhanced }\end{array}$ & - & - \\
\hline
\end{tabular}

The following is the summary of the PCHE design constraints and guidelines used in this paper. These are based on the information provided by Gezelius [6] and Heatric [7] for application of PCHEs to the VHTRs.

(1) Semi-circular cross-section

(2) Width: $0.1 \sim 0.2(2.0 \mathrm{~mm}$ shows maximum thermal performance and economic efficiency but for nuclear application, $1.2 \mathrm{~mm}$ is suggested.)

(3) Depth: $0.5 \sim 1.0 \mathrm{~mm}$

(4) Carbon steel is typically not used because of the small channel diameter vulnerable to corrosion and unsuitability for diffusion bonding.

(5) Average mass-to-duty ratio: 0.2 tones/MW (13.5 tones/MW in shell-and-tube design)

(6) No constraint to the pressure drop

(7) Plate thickness: 0.8D (D: channel diameter)

(8) Channel pitch: 1.22D (D: channel diameter)

(9) Multiported PCHE module size: width: $0.5 \mathrm{~m}(1.5 \mathrm{~m}$ is max), height: $0.6 \mathrm{~m}$, depth: $0.4 \sim 0.6 \mathrm{~m}$.

(10) Fatigue can be caused by thermal transient.

(11) Only pressure drop restricts the velocity. 
(12) Minimum life is 20 years.

For thermal design of the helical coil heat exchanger, we followed the similar methods to the shell-and-tube heat exchanger design since there is no well-published guideline for this heat exchanger. However, heat transfer and friction loss correlations were replaced with adequate ones considering helical coil effects. Those correlations were obtained from the general heat transfer reference books $[1,8]$.

Alloy 617 was selected to be the reference material based on the material selection studies for VHTR IHXs by Dewson and Li [9]. They selected eight candidate materials based on ASME VIII (Boiler and Pressure Vessel Code) and compared them together. The materials include Alloy 617, Alloy 556, Alloy $800 \mathrm{H}$, Alloy 880 HT, Alloy 330, Alloy 230, Alloy HX and 253 MA. They extensively compared the mechanical properties, physical properties and corrosion resistance for the candidate materials, and finally concluded that Alloy 617 and 230 are the most suitable materials for an IHX. The sensitivity of material types on the heat exchanger thermal design was not considered in this paper since the types of materials show negligible effect on the heat exchanger thermal design according to Natesan et al. [10]'s study. Even for the ceramic materials, only about $13 \%$ size reduction was reported [10].

\section{HEAT EXCHANGER THERMAL DESIGN}

In order to design an IHX, we need to determine design requirements and conditions for the heat exchanger. For VHTR applications, the following are general requirements for an IHX.

- Maximum operating temperature: $\sim 1000{ }^{\circ} \mathrm{C}$

- Pressure: $50 \sim 100$ bar

- Duty: $600 \mathrm{MWt}$

- Effectiveness: $95 \%$

- Helium environment

- Low pressure drop

- $\quad 30 \sim 60$ year design life

Figure 1 shows the schematics of the reference VHTR system selected in this paper (Oh et al. [11]) for IHX thermal design. In this system, there are three coolant loops; (1) primary, (2) secondary and (3) intermediate. The primary side contains the nuclear reactor, the hot side of the IHX, and a compressor. The secondary side contains the cold side of the IHX, the hot side of the secondary heat exchanger (SHX), the PCU, and connecting piping, which is assumed to be short. The IHX connects the primary and secondary loops. The intermediate heat transport loop connects the secondary coolant system to the high temperature steam electrolysis (HTSE) plant through several process heat exchangers (PHXs). The flow in the secondary coolant system is divided, with most of the flow going towards the PCU and the remainder going through a SHX that directs heat towards the HTSE plant. The flow through the hot side of the SHX is then mixed with the flow from the PCU to feed the cold side of the intermediate heat exchanger (IHX). However, some of the flow is diverted away from the PCU, which acts to decrease the efficiency of the cycle. There are three coolant loops.

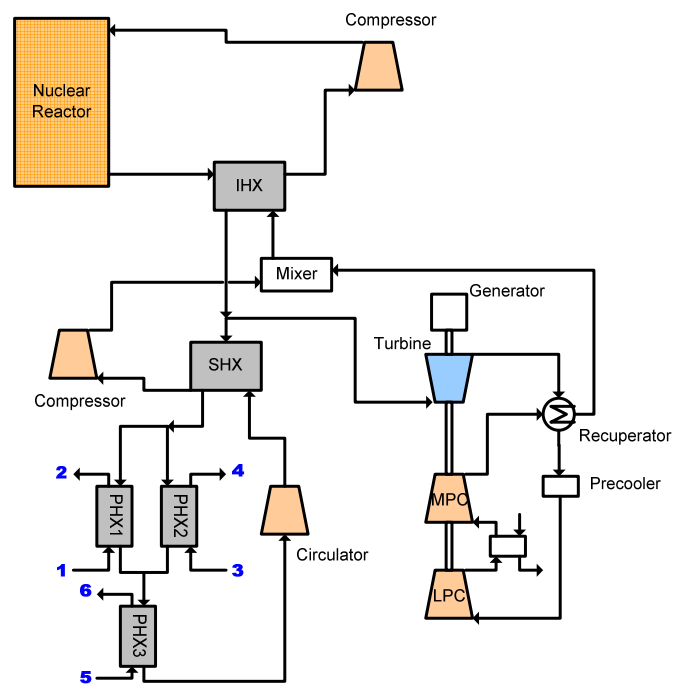

Figure 1. Reference VHTR system (Indirect Parallel Configuration [11])

For this configuration, Oh et al. [11] estimated the operating conditions and system thermal performance by using HYSYS process analysis code [12]. Table 2 summarizes the operating conditions reported for the IHX in Figure 1. All the thermal design in this paper is carried out based on these operating and design conditions. In this paper, only IHX was taken into consideration in the thermal design. SHXs and PHXs in Figure 1 were not covered here.

Table 2. Heat Exchanger Design Conditions.

\begin{tabular}{|c|c|}
\hline & IHX \\
\hline Duty [MWt] & 611 \\
\hline${ }^{*} \mathrm{LMTD}\left[{ }^{\circ} \mathrm{C}\right]$ & 45.37 \\
\hline Tube Side Coolant & $\mathrm{He}$ \\
\hline Shell Side Coolant & $\mathrm{He}$ \\
\hline Tube Inlet Temperature $\left[{ }^{\circ} \mathrm{C}\right]$ & 900 \\
\hline Tube Outlet Temperature $\left[{ }^{\circ} \mathrm{C}\right]$ & 594.5 \\
\hline Tube Side Pressure [MPa] & 7 \\
\hline Mass Flow in Tube Side [kg/s] & 385.3 \\
\hline Shell Inlet Temperature $\left[{ }^{0} \mathrm{C}\right]$ & 492.5 \\
\hline Shell Outlet Temperature $\left[{ }^{\circ} \mathrm{C}\right]$ & 884.8 \\
\hline Shell Side Pressure [MPa] & 7.584 \\
\hline Mass Flow in Shell Side [kg/s] & 300 \\
\hline
\end{tabular}

* *LMTD (log mean temperature difference). 


\section{a. Thermal Design of Single-Stage IHX}

A single-stage IHX is the most general type of the arrangement options. In this layout, the IHX consists of one heat exchanger (HX) unit or separate modules aligned in parallel. There is no serial combination of IHXs. As mentioned, three different HX types were designed here; PCHE, Shell and Tube and Helical coil. Table 3, 4 and 5 summarizes the design specifications estimated for each IHX type. Design conditions are based on the Table 2 as mentioned. For design and rating of the heat exchangers, HYSYS code and excel spreadsheet were used. PCHE heat exchanger design has been performed based on the method proposed by Hesselgreaves [2], and shell-andtube heat exchanger by Kern [5]. Detail design procedure and equations are not described in this paper.

Table 3 summarizes the estimated IHX design specifications for PCHE option. The total core volume was estimated to range from 4.78 to $5.29 \mathrm{~m}^{3}$ for a given pressure drop requirement $(\mathrm{dP}<70 \mathrm{kPa})$. Total heat transfer surface area is about $6000 \mathrm{~m}^{2}$. In this thermal design, mechanical design factors are not considered yet. Therefore, the exact values specified here could have some discrepancies with the final design specifications afterward.

Table 3. Estimated IHX thermal design specifications for PCHE - Single Stage Option.

\begin{tabular}{|c|c|}
\hline Duty [MWt] & 612 \\
\hline LMTD [C] & 45.57 \\
\hline $\mathbf{U}\left[\mathbf{W} / \mathbf{m}^{2} \mathbf{K}\right]$ & 2313 \\
\hline$A\left[m^{2}\right]$ & 5805 \\
\hline Channel Diameter [m] & $1.20 \mathrm{E}-03$ \\
\hline Channel Pitch [m] & $1.46 \mathrm{E}-03$ \\
\hline Plate Thickness [m] & $9.60 \mathrm{E}-04$ \\
\hline Surface Area Density $\left[\mathrm{m}^{2}\right]$ & 2195 \\
\hline Ratio of free flow and frontal area & 0.2148 \\
\hline Effective Diameter [m] & $7.33 \mathrm{E}-04$ \\
\hline Stack Width [m] & 0.6 \\
\hline Stack Length [m] & 0.43 \\
\hline Stack Height [m] & 0.6 \\
\hline \# of Stacks & 34 \\
\hline Total Core Volume $\left[\mathrm{m}^{3}\right]$ & 5.29 \\
\hline HTC - Primary $\left[W / m^{2} K\right]$ & 5514 \\
\hline HTC - Secondary $\left[\mathrm{W} / \mathrm{m}^{2} \mathrm{~K}\right]$ & 4116 \\
\hline Pressure Drop (Primary) [kPa] & 66.83 \\
\hline Pressure Drop (Secondary) [kPa] & 31.76 \\
\hline
\end{tabular}

Table 4 summarizes the estimated design specifications of the shell-and-tube heat exchangers. Two different tube configurations were considered in this paper; (1) straight pipe and (2) U-tube. The total volume ranges are obtained to range between 379 and $483 \mathrm{~m}^{3}$. It is much larger than the volume for the PCHEs in Table 3. There are two reasons for this. First, the surface area densities of PCHEs are much smaller than the shell-and-tube heat exchangers because of the small channel diameters. Second, the heat transfer coefficients are much larger in the PCHEs as shown in Table 3 and 4. The larger heat transfer coefficient is also originated from the smaller channel diameters significantly reducing thermal boundary layers thickness.

Table 5 summarizes the design specification of the helical coil heat exchangers. The diameters, thickness and pitches of the tubes of this heat exchanger were selected to be the same as the standard shell-and-tube type in Table 4. However, in the practical applications, this exchanger type usually requires larger tube size than general shell-and-tube heat exchangers because of manufacturing difficulties. Therefore, the estimated design parameters in Table 5 could be different from the real designs. In our estimation, the volume and heat transfer area of this exchanger are placed between PCHEs and shell-and-tube heat exchangers. The reason why it shows smaller size and surface area than the standard shell-and-tube heat exchanger is because of the heat transfer enhancement by helical coil.

Table 4. Estimated IHX thermal design specifications for Shelland-Tube- Single Stage Option.

\begin{tabular}{|c|c|c|}
\hline & Straight Tube & U Tube \\
\hline Duty [MWt] & 612 & 612 \\
\hline LMTD [C] & 45.57 & 45.54 \\
\hline $\mathbf{U}\left[\mathbf{W} / \mathbf{m}^{2} \mathbf{K}\right]$ & 380.5 & 474 \\
\hline $\mathbf{A}[\mathrm{m} 2]$ & $3.53 \mathrm{E}+04$ & $2.83 \mathrm{E}+04$ \\
\hline Tube Inner Diameter [mm] & $1.80 \mathrm{E}+01$ & $1.80 \mathrm{E}+01$ \\
\hline Tube Outer Diameter [mm] & $2.00 \mathrm{E}+01$ & $2.00 \mathrm{E}+01$ \\
\hline Tube Pitch [mm] & $3.00 \mathrm{E}+01$ & $3.00 \mathrm{E}+01$ \\
\hline Pitch-to-diameter ratio & 1.5 & 1.5 \\
\hline Tube Length $[\mathrm{m}]$ & 19.56 & 15.42 \\
\hline Tube Thickness [mm] & $1.00 \mathrm{E}+00$ & $1.00 \mathrm{E}+00$ \\
\hline \# of Tubes & $2.87 \mathrm{E}+04$ & 2.924 \\
\hline Shell Diameter [m] & 5550 & 5600 \\
\hline Baffle Spacing [m] & 4000 & 4000 \\
\hline Aspect Ratio & 0.28 & 0.3631 \\
\hline Total Core Volume $\left[\mathrm{m}^{3}\right]$ & 473 & 379.9 \\
\hline $\begin{array}{l}\text { Pressure Drop (Tube Side) } \\
{[\mathrm{kPa}]}\end{array}$ & 13 & 73.11 \\
\hline $\begin{array}{l}\text { Pressure Drop (Shell Side) } \\
{[\mathrm{kPa}]}\end{array}$ & 69.83 & 57.15 \\
\hline
\end{tabular}


Table 5. Estimated IHX thermal design specifications for Helical Coil - Single Stage Option.

\begin{tabular}{|l|c|}
\hline Duty [MWt] & 612 \\
\hline LMTD $[\mathbf{C}]$ & 45.58 \\
\hline $\mathbf{U}\left[\mathbf{W} / \mathbf{m}^{2} \mathbf{K}\right]$ & 1189 \\
\hline A $\left.\mathbf{m}^{2}\right]$ & $1.354 \mathrm{e} 4$ \\
\hline Tube Inner Diameter [mm] & 18 \\
\hline Tube Outer Diameter [mm] & 2 \\
\hline Tube Pitch [mm] & 30 \\
\hline Pitch-to-diameter Ratio & 1.5 \\
\hline Number of Tubes & 5025 \\
\hline Number of Coiled Columns & 3.33 \\
\hline Shell Inner Diameter [m] & 0.49 \\
\hline Shell Outer Diameter [m] & 4.6 \\
\hline Shell Length [m] & 9.86 \\
\hline Volume [m $\left.\mathbf{m}^{\mathbf{3}}\right]$ & 163.8 \\
\hline Aspect Ratio (Ds/L) & 0.47 \\
\hline dP (tube) [kPa] & 66.57 \\
\hline dP (shell) [kPa] & 62.51 \\
\hline
\end{tabular}

\section{Comparisons of Heat Exchanger Types}

Based on the design specifications summarized in Table 3, 4 and 5, three types of heat exchangers were compared for application of VHTR IHXs as follows.

- The size of a HX can be represented by its total volume. In high temperature applications, the smaller volume of HXs is generally preferred since (1) the high alloy metals or ceramics are very costly, and (2) the smaller HXs can reduce the total system size. PCHEs provide a much smaller size than other types.

- In VHTRs, a smaller heat transfer area is preferred since large heat transfer areas can permeate tritium into the hydrogen plant, which is a very serious problem in the hydrogen production system integrated with VHTRs. PCHEs provide the lowest surface area.

- Fewer modules are preferred for design simplicity. Helical type heat exchangers look to provide the simplest system configuration.

- In high temperature applications, thermal stress is an important issue. The high compactness of the PCHE offers great heat performance, but has some potential problems on the thermal stress in the axial direction, where the sharp temperature variations occur.

- Shell-and-tube type HXs are well proven technology in the industry. Especially, Helical coil HXs have a great operating history and their use in the HTTR of Japan has shown a long lifetime. Technically, PCHE types show good potential for high temperature applications, but don't have much history of use.

- Shell-and-tube type HXs are a proven technology. Therefore, the problems and limitations of these HXs are very well identified.

- Generally, shell-and-tube type HXs allow in-service inspections and have well-established maintenance methods. However, regarding PCHEs, it is difficult to find defects and failures in operation and it is not easy to maintain compared to shell-and-tube HXs.

\section{b. Thermal Design of a Split Two-Stage IHX}

Another option of the IHX layout is the two-stage arrangement. This option was recommended in order to reduce associated risk and cost.. In this concept, two HXs are arranged and connected in serial. The low temperature section is designed to last the full plant lifetime. In this section the maximum temperature is proposed to be around $760{ }^{\circ} \mathrm{C}$, allowed in ASME Section III, Subsection NH materials. The high temperature section is designed for replacement within the plant lifetime. Alloy 617 and 230 are the potential candidates. Figure 2 shows the flow schematics and design conditions for each section estimated by HYSYS code. The overall design conditions are the same as the single-stage IHX in Table 2. However, it was split into two parts. It is notable that splitting the HXs highly affects log mean temperature differences (LMTD) required for both sides. For example, in the high temperature section, the LMTD decreases to $31.69^{\circ} \mathrm{C}$ while in the low temperature section, it increases to $77.74{ }^{\circ} \mathrm{C}$ compared to LMTD in the single-stage IHX, $45.37{ }^{\circ} \mathrm{C}$.

Table 6 through 8 summarizes the design specifications estimated for the two-stage IHXs. For each section, all of the three types of heat exchangers (PCHE, shell-and-tube, helical coil) were designed. Therefore, totally, 6 different heat exchanger design specifications were obtained. The same design methods and parameters (channel diameters, pitches and thickness) as in the single-stage IHX design were also used here. The pressure drop for each section was also determined within the total pressure drop, $70 \mathrm{kPa}$ to match the single-stage IHX design.

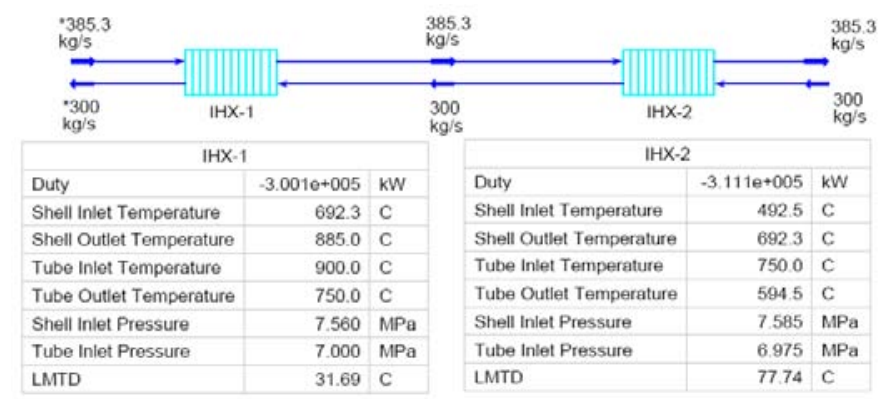

Figure 2. Design Conditions for Two-Stage IHX. 
Table 6. Estimated IHX thermal design (PCHE) - Two Stage.

\begin{tabular}{|c|c|c|}
\hline & HT Unit & LT Unit \\
\hline Duty [MWt] & 300 & 312 \\
\hline LMTD [C] & 31.74 & 77.82 \\
\hline $\mathbf{U}[\mathbf{W} / \mathbf{m} 2 \mathbf{K}]$ & 2410 & 2735 \\
\hline A [m2] & 3928 & 1464 \\
\hline Channel Diameter [m] & $1.20 \mathrm{E}-03$ & $1.20 \mathrm{E}-03$ \\
\hline Channel Pitch [m] & $1.46 \mathrm{E}-03$ & $1.46 \mathrm{E}-03$ \\
\hline Plate Thickness [m] & $9.60 \mathrm{E}-04$ & $9.60 \mathrm{E}-04$ \\
\hline Surface Area Density $\left[\mathrm{m}^{2}\right]$ & 2195 & 2195 \\
\hline Ratio of free flow and front al area & 0.2148 & 0.2148 \\
\hline Stack Width [m] & 0.6 & 0.16 \\
\hline Stack Length $[\mathrm{m}]$ & 0.29 & 0.14 \\
\hline Stack Height $[\mathrm{m}]$ & 0.6 & 0.6 \\
\hline \# of Stacks & 34 & 100 \\
\hline Total Core Volume $\left[\mathrm{m}^{3}\right]$ & 3.569 & 1.334 \\
\hline $\begin{array}{l}\text { Pressure Drop (Primary) } \\
{[\mathrm{kPa}]}\end{array}$ & 49.2 & 30.45 \\
\hline $\begin{array}{l}\text { Pressure Drop (Secondary) } \\
{[\mathrm{kPa}]}\end{array}$ & 26.89 & 21.74 \\
\hline
\end{tabular}

Table 7. Estimated IHX thermal design (Shell and Tube) - Two Stage.

\begin{tabular}{|l|c|c|}
\hline & HT Unit & LT Unit \\
\hline Duty [MWt] & 300 & 312 \\
\hline LMTD [C] & 31.74 & 77.83 \\
\hline U [W/m $\left.{ }^{2} \mathbf{K}\right]$ & $4.90 \mathrm{E}+02$ & $4.61 \mathrm{E}+02$ \\
\hline A [m2] & $1.93 \mathrm{E}+04$ & $8.69 \mathrm{E}+03$ \\
\hline Tube Inner Diameter [mm] & $1.80 \mathrm{E}+01$ & $1.80 \mathrm{E}+01$ \\
\hline Tube Outer Diameter [mm] & $2.00 \mathrm{E}+01$ & $2.00 \mathrm{E}+01$ \\
\hline Tube Pitch [mm] & $3.00 \mathrm{E}+01$ & $3.00 \mathrm{E}+01$ \\
\hline Pitch-to-diameter ratio & 1.5 & 1.5 \\
\hline Tube Length [m] & 10.16 & 4.564 \\
\hline Tube Thickness [mm] & $1.00 \mathrm{E}+00$ & $1.00 \mathrm{E}+00$ \\
\hline \# of Tubes & $3.03 \mathrm{E}+04$ & $3.03 \mathrm{E}+04$ \\
\hline Shell Diameter [m] & 5700 & 5700 \\
\hline Aspect Ratio & 0.56 & 1.249 \\
\hline Total Core Volume [m $\left.{ }^{3}\right]$ & 259 & 116.5 \\
\hline Pressure Drop (Tube Side) [kPa] & 53.88 & 26.95 \\
\hline Pressure Drop (Shell Side) [kPa] & 41.07 & 24.84 \\
\hline
\end{tabular}

In the two-stage IHX layout, each section can have three different heat exchanger types independently. Therefore, total nine serial combinations are available for options as shown in Table 9.

Table 10 summarizes the heat exchanger core volumes for each option. The volumes specified in this table were obtained from Table 5,6 and 7. As shown in Table 10, it is obvious that
C1 (PCHE-PCHE) has the smallest total volume with the highest compactness (surface area density $=2195 \mathrm{~m}^{-1}$ ). Especially, the smaller size of the high temperature unit is highly recommended for cost saving and safety enhancement. Because of the material problems from severe high temperature conditions, careful considerations are necessary for selection and design of the high temperature related components. If the high temperature unit becomes smaller, less effort and cost will be required for manufacturing and maintenance. In addition, the size reduction will enhance the component safety by reducing the probability of an incident.

Table 8. Estimated IHX thermal design (Helical Coil) - Two Stage.

\begin{tabular}{|c|c|c|}
\hline & HT Unit & LT Unit \\
\hline Duty [MWt] & 300 & 312 \\
\hline LMTD [C] & 31.74 & 77.83 \\
\hline $\mathbf{U}\left[\mathbf{W} / \mathbf{m}^{2} \mathbf{K}\right]$ & 1249 & 1176 \\
\hline $\mathbf{A}\left[\mathbf{m}^{2}\right]$ & 7580 & 3405 \\
\hline Tube Inner Diameter [mm] & 18 & 18 \\
\hline Tube Outer Diameter [mm] & 2 & 2 \\
\hline Tube Pitch [mm] & 30 & 30 \\
\hline Pitch-to-diameter Ratio & 1.5 & 1.5 \\
\hline Number of Tubes & 5025 & 5025 \\
\hline Number of Coiled Columns & 3.007 & 1.35 \\
\hline Shell Inner Diameter [m] & 0.4883 & 0.49 \\
\hline Shell Outer Diameter [m] & 4.6 & 4.6 \\
\hline Shell Length [m] & 6.614 & 2.97 \\
\hline Volume $\left[\mathrm{m}^{3}\right]$ & 109.9 & 49.38 \\
\hline Aspect Ratio (Ds/L) & 0.7 & 1.5 \\
\hline dP (tube) [kPa] & 44.67 & 17.51 \\
\hline dP (shell) [kPa] & 52.87 & 18.84 \\
\hline
\end{tabular}

Table 11 shows the estimated heat transfer area for the HXs in serial configurations. As predicted, C1 (PCHE-PCHE) shows the smallest heat transfer area. This is because of the decrease of the thermal boundary layer by reducing channel diameter. The heat transfer surface areas of other combinations are at least three times larger than the area of $\mathrm{C} 1$.

Table 9. Heat exchanger combinations in the two-stage IHX

\begin{tabular}{|c|c|c|}
\hline Case & HT Unit & LT Unit \\
\hline C1 & PCHE & PCHE \\
\hline C2 & PCHE & Shell and Tube \\
\hline C3 & PCHE & Helical Coil \\
\hline C4 & Shell and Tube & PCHE \\
\hline C5 & Shell and Tube & Shell and Tube \\
\hline C6 & Shell and Tube & Helical Coil \\
\hline C7 & Helical Coil & PCHE \\
\hline C8 & Helical Coil & Shell and Tube \\
\hline C9 & Helical Coil & Helical Coil \\
\hline
\end{tabular}


Table 10. Volume $\left(\mathrm{m}^{3}\right)$ of HXs for Two-stage IHX.

\begin{tabular}{|c|c|c|c|}
\hline Case & HT Unit & LT Unit & Total \\
\hline C1 & 3.5 & 1.334 & 4.834 \\
\hline C2 & 3.5 & 116.5 & 120 \\
\hline C3 & 3.5 & 49.38 & 52.88 \\
\hline C4 & 259 & 1.334 & 260.334 \\
\hline C5 & 259 & 116.5 & 375.5 \\
\hline C6 & 259 & 49.38 & 308.38 \\
\hline C7 & 109.9 & 1.334 & 111.23 \\
\hline C8 & 109.9 & 116.5 & 225 \\
\hline C9 & 109.9 & 49.38 & 159.28 \\
\hline
\end{tabular}

Table 11. Heat Transfer Area $\left(\mathrm{m}^{2}\right)$ of Two-stage IHX.

\begin{tabular}{|c|c|c|c|}
\hline Case & HT Unit & LT Unit & Total \\
\hline C1 & 3877 & 1464 & 5341 \\
\hline C2 & 3877 & 8690 & 12567 \\
\hline C3 & 3877 & 3405 & 7282 \\
\hline C4 & 19300 & 1464 & 20764 \\
\hline C5 & 19300 & 8690 & 27990 \\
\hline C6 & 19300 & 3405 & 22705 \\
\hline C7 & 7580 & 1464 & 9044 \\
\hline C8 & 7580 & 8690 & 16270 \\
\hline C9 & 7580 & 3405 & 10985 \\
\hline
\end{tabular}

In the two-stage design, the total duty was split in half (300MWt / 300MWt). However, the high temperature section requires more than twice of the volume and surface area of the lower temperature section. This is because of the reduced LMTD in the high temperature section. The total average LMTD is $45 \sim 50{ }^{\circ} \mathrm{C}$, but it reduces to about $30{ }^{\circ} \mathrm{C}$ in the high temperature section. The decrease of the LMTD requires larger heat transfer surface area for the same duty. It still means that most parts of the HXs should be operated in the high temperature region.

To reduce the size of the high temperature section, the separation temperature has been adjusted to $800^{\circ} \mathrm{C}$. Increase of separation temperature leads to the decrease of duty in the high temperature section, and it also leads to the heat exchanger size decrease. However, the increase of the separation temperature makes the low temperature section more vulnerable to the stress. The details about the stress analysis are described in the following sections.

Tables 12 and 13 summarize the volumes and heat transfer surface areas for two-stage IHXs at the increased separation temperature $\left(800^{\circ} \mathrm{C}\right)$. The volumes and surface areas were estimated by the same method as used for the design at the original separation temperature $\left(750^{\circ} \mathrm{C}\right)$. When we increase the separation temperature up to $800^{\circ} \mathrm{C}$, the size of the high temperature section was reduced to about a half of the total volume as shown in Table 11. Since the high temperature section is a replaceable during the plant lifetime, PCHEs, which have a smaller size, will be more beneficial leading to lower cost and easier maintenance.

Table 12. Volume $\left(\mathrm{m}^{3}\right)$ of HXs for Two-stage IHX

$$
\left(\mathrm{T}_{\text {separtion }}=800^{\circ} \mathrm{C}\right) \text {. }
$$

\begin{tabular}{|c|c|c|c|}
\hline Case & HT Unit & LT Unit & Total \\
\hline C1 & 2.549 & 2.019 & 4.568 \\
\hline C2 & 2.549 & 173.6 & 176.15 \\
\hline C3 & 2.549 & 73.63 & 76.179 \\
\hline C4 & 201.9 & 2.019 & 203.92 \\
\hline C5 & 201.9 & 173.6 & 375.5 \\
\hline C6 & 201.9 & 73.63 & 275.53 \\
\hline C7 & 85.58 & 2.019 & 87.599 \\
\hline C8 & 85.58 & 173.6 & 259.18 \\
\hline C9 & 85.58 & 73.63 & 159.21 \\
\hline
\end{tabular}

Table 13. Heat Transfer Area $\left(\mathrm{m}^{2}\right)$ of Two-stage IHX.

\begin{tabular}{|c|c|c|c|}
\hline & HT Unit & LT Unit & Total \\
\hline C1 & 2792 & 2216 & 5008 \\
\hline C2 & 2792 & 13000 & 15792 \\
\hline C3 & 2792 & 5077 & 7869 \\
\hline C4 & 19300 & 2216 & 17216 \\
\hline C5 & 19300 & 13000 & 28000 \\
\hline C6 & 19300 & 5077 & 24377 \\
\hline C7 & 5901 & 2216 & 8117 \\
\hline C8 & 5901 & 13000 & 18901 \\
\hline C9 & 5901 & 5077 & 10978 \\
\hline
\end{tabular}

\section{c. Comparisons of IHX Options}

In this section, the single-stage IHX and two-stage IHX were compared based on the results summarized in Table 3 through 13.

\section{Total HX core volume}

In high temperature applications, the smaller volume of HX is generally preferred. However, the total core size of the $\mathrm{HX}$ is not affected by HX layout. It means that splitting the IHX does not lead to any size increases or decrease of the HX core. However, practically, a two-stage IHX will require more space for manifold of flow distribution. But, it is negligible. 


\section{- Total Heat Transfer Area}

Heat transfer area is another important parameter in VHTR applications. In the hydrogen production system integrated with the VHTRs, tritium permeation into a hydrogen plant is a serious problem. A smaller heat transfer area can reduce the tritium permeation rate. However, the total heat transfer area of the HX is not affected by the HX layout. It means that splitting the IHX does not lead to any size increases or decrease of the HX surface area.

\section{- Size of high temperature section}

The smaller size of the high temperature unit is preferred, because it can reduce the maintenance cost and enhance component safety. The two-stage IHX with an $800^{\circ} \mathrm{C}$ separation temperature has the lowest high temperature section size. A single stage IHX has the largest high temperature section size.

\section{- System complexity}

The number of modules is related to the system complexity. Fewer modules are preferred for simplicity. The single stage IHX has the simplest design, because of less number of modules.

According to the above comparisons, conceptually, the two-stage PCHEs separation temperature are expected to offer more advantages in system cost, safety and maintenance compared to the single-stage IHXs. For example, material cost can be saved in the two-stage IHXs since some cheap commercial materials like stainless steel or Alloy $800 \mathrm{H}$ can replace high alloy materials in the low temperature sections. In addition, it provides easier management and controllability of risks by concentrating safety issues on the high temperature sections. The thermal stress can also be relieved in the twostage IHXs by reducing temperature differences in the two components. On the other hands, a single stage PCHE provides a quite small size and simplicity.

In the thermal design, two-stage heat exchangers using PCHEs with a separation temperature of $800{ }^{\circ} \mathrm{C}$ is recommended for an IHX. Using the standard shell-and-tube heat exchanger is not recommended for VHTR applications here. However, to avoid some risks about the lack of experience using PCHEs as IHXs, single-stage helical coil heat exchangers can be another option since it is proved in the operation of the HTTR.

\section{HEAT EXCHANGER SIMPLE STRESS ANALYSIS}

A simplified stress analysis was performed in order to estimate the mechanical performance of the IHX options.We estimated the required thickness in which the circumferential stress was less than or equal to an assumed allowable value. The use of consistent stresses allowed identification of limiting components and a fair comparison between different configurations.
Since the IHX and SHX operate in a high temperature environment, the creep deformation is important, and Subsection NH of ASME Code, Section III is applicable. However, there are several problems with applying ASME Section III code rules at this time. The use of the primary candidate, structural Alloy 617, is currently not approved in Subsection NH. So, we used a draft code case for designs using Alloy 617, to obtain the allowable stress for our stress analysis. The primary stress limit of the Alloy 617 draft code case was well summarized by Natesan et. al. [10].

Figure 3 shows allowable stress $\left(\mathrm{S}_{\mathrm{mt}}\right)$ vs. Lifetime for Alloy 617. These data were obtained from Alloy 617 draft code case [10] as mentioned. The plot shows the lifetime data as a function of allowable stress for three different temperatures; $750^{\circ} \mathrm{C}, 800^{\circ} \mathrm{C}$ and $900{ }^{\circ} \mathrm{C}$. This graph displays the maximum operating lifetime at the given stress load. As the stress increases, the lifetime decreases exponentially. Since the maximum available lifetime data is $1 \times 10^{5} \mathrm{hrs}$ (about 10 years), the values beyond this life time were predicted by a simple linear extrapolation method. For more accurate analyses, available experimental data or proven extrapolation methods should be measured or developed afterward.

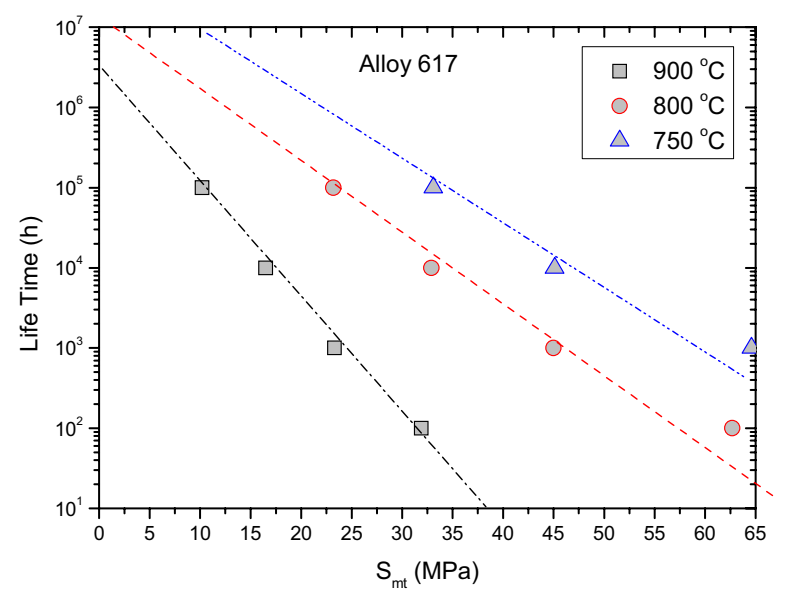

Figure 3. $\mathrm{S}_{\mathrm{mt}}(\mathrm{MPa})$ vs. Life Time (h) for Alloy 617.

Table 14 summarizes the assumed allowable stresses for Alloy 617 predicted by interpolation and extrapolation of Figure 3. The stress analyses of this paper have been carried out based on the allowable stresses assumed in this table.

Table 14. Assumed Allowable Stresses for Alloy 617.

\begin{tabular}{|c|c|c|c|}
\hline & \multicolumn{3}{|c|}{ Allowable Stress (MPa) } \\
\hline Temperature & $\mathbf{1 0}^{\mathbf{5}}$ hours & $\mathbf{1 0}^{\mathbf{6}}$ hours & $\mathbf{5 x 1 0}^{\mathbf{6}}$ hours \\
\hline $750^{\circ} \mathrm{C}$ & 33.1 & 25 & 15 \\
\hline $800^{\circ} \mathrm{C}$ & 23.2 & 12.3 & 5.0 \\
\hline $900^{\circ} \mathrm{C}$ & 10.2 & 3.5 & - \\
\hline
\end{tabular}


The required thickness for the IHX channel walls were estimated based on the simple stress and failure theory. For thick walled cylinders, the tangential stress, $\sigma$, is calculated as [13]

$$
\sigma=\frac{P_{i}\left[\left(r_{0} / r_{i}\right)^{2}+1\right]-P_{0}\left[\left(r_{0} / r_{i}\right)^{2}+\left(r_{0} / r\right)^{2}\right]}{\left(r_{0} / r_{i}\right)^{2}-1}
$$

where $r$ is the radius, $P$ is the pressure, and the subscript $i$ and $o$ refer to the inner and outer surface, respectively. The stress is negative if the external pressure exceeds the internal pressure, but the maximum magnitude always occurs at the inner surface. The radius ratio that causes the maximum stress to be less than or equal to the allowable stress, $\sigma_{D}$, can be calculated from Eq. (1). For cases where the internal pressure exceeds the external pressure, the limiting ratio is

$$
\frac{r_{o}}{r_{i}} \geq \sqrt{\frac{\sigma_{D}+P_{i}}{\sigma_{D}+2 P_{0}-P_{i}}} .
$$

For cases where the external pressure exceeds the internal pressure, the maximum absolute value of the stress will be less than or equal to the allowable stress when the radius ratio is

$$
\frac{r_{o}}{r_{i}} \geq \sqrt{\frac{\sigma_{D}-P_{i}}{\sigma_{D}-2 P_{0}-P_{i}}} .
$$

A stress analysis was also performed for the IHX assuming that it is a compact heat exchanger of the type designed by Heatric [7]. The design of the heat exchanger channels is defined by the channel diameter, $d$, pitch $\mathrm{p}$, and plate thickness, $t_{p}$. Following the method used by Dostal et al. [14], the minimum wall thickness between channels, $t_{f}$, can be approximated as

$$
t_{f} \geq \frac{p}{\frac{\sigma_{D}}{\Delta P}+1},
$$

where $\sigma_{D}$ is the allowable stress and $\Delta P$ is the differential pressure between the hot and cold streams. Expressing Eq. (4) in terms of pitch-to-diameter ratio yields

$$
\frac{p}{d} \geq 1+\frac{\Delta P}{\sigma_{D}} .
$$

The required plate thickness can also be calculated based on the method of Dostal et al. [14]. The plate is assumed to be a thick-walled cylinder, with an inner radius of $d / 2$ and an outer radius of $t_{p}$.

Engineering problems concerned with the design and development of structural or machine parts generally involve biaxial (occasionally triaxial) stresses. However, available strength data usually pertains to uniaxial stress, and often only to uniaxial tension. To resolve this problem, a failure theory is used in the engineering practice. The failure theories are generally based on the assumption that tensile yielding occurs as a result of exceeding the capacity of the materials in one or more respects, such as:

(a) Capacity to withstand normal stress (Maximum Normal Stress Theory),

(b) Capacity to withstand shear stress (Maximum Shear Stress Theory),

(c) Capacity to withstand normal strain (Maximum Normal Strain Theory),

(d) Capacity to withstand shear strain (Maximum Shear Strain Theory), and

(e) Capacity to absorb strain energy (Total Strain Energy Theory),

(f) Capacity to absorb distortion energy (Maximum Distortion Energy Theory).

Hence, in the simple classical theories of failure, it is assumed that the same amount of whatever caused the selected tensile specimen to fail will also cause any part made of the materials to fail regardless of the state of stress involved. The model details are well described in Collins [15].

The lifetimes of the reference HXs designed in the thermal design section has been estimated by the failure theory (Ref) and they were summarized in Table 15 . The life time was estimated by the maximum shear stress theory which is generally the most conservative. The maximum pressure differences were set to be $1.0 \mathrm{MPa}$ between the hot and cold channels. In the reference HXs, the thickness-to-inner radius ratios (t/ri) are 0.6 for PCHE and 0.1 for Tubular type. Generally, since the PCHE has larger $t / r$ i values than the tubular type HXs, the life time of the PCHE is larger than the tubular type. If the thickness-to-inner radius ratio in the tubular type HX is increased, the lifetime will be increased. However, the $\mathrm{t} / \mathrm{ri}$ values in the commercial tubing ranges from 0.1 to 0.5 , and most of them are within 0.3. According to Table 15, both PCHE and Tubular type (shell-and-tube and helical coil) are all possible for operating in the whole life time if the thickness of the wall is sufficiently large. However, if the required pressure drop between hot and cold channels is increased to $5 \mathrm{MPa}$ (this is usually required for SHX application.), the life time of the heat exchangers are significantly dropped to $1.2 \mathrm{X} 10^{4}$ hours and 149 hours for PCHE and Tubular types, respectively.

Table 15. Estimated Life Time of Reference IHXs.

\begin{tabular}{|c|c|c|}
\hline \multirow{2}{*}{ Temperature } & \multicolumn{2}{|c|}{ Life Time (hrs) } \\
\hline \multirow{2}{*}{} & \multicolumn{2}{|c|}{ IHX } \\
\cline { 2 - 3 } & PCHE & Tubular Type \\
\hline $750^{\circ} \mathrm{C}$ & $3.3 \times 10^{7} \mathrm{hrs}$ & $8.5 \times 10^{6} \mathrm{hrs}$ \\
\hline $800^{\circ} \mathrm{C}$ & $6.7 \times 10^{6} \mathrm{hrs}$ & $1.7 \times 10^{6} \mathrm{hrs}$ \\
\hline $900^{\circ} \mathrm{C}$ & $1.1 \times 10^{6} \mathrm{hrs}$ & $4.1 \times 10^{5} \mathrm{hrs}$ \\
\hline
\end{tabular}


Figures 4 and 5 show sample cases of the estimated maximum allowable pressure difference between the inside and outside of the tubes as a function of the $t / r_{i}$ value for a given temperature and lifetime. Therefore, the $\Delta \mathrm{P}_{\max }$ should always be designed larger than the $\triangle \mathrm{P}$ in the SHX or IHX. According to these results, $\Delta \mathrm{P}_{\max }$ values don't look highly dependent on the tube inner diameter or HX types.

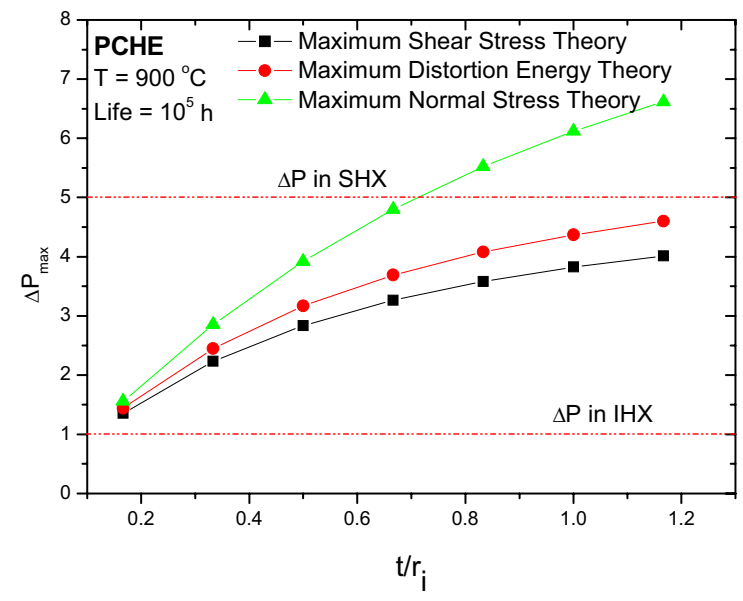

Figure 4. Thickness-to-inner radius ratio $\left(\mathrm{t} / \mathrm{r}_{\mathrm{i}}\right) \mathrm{vs}$. Maximum allowable pressure difference $\left(\Delta \mathrm{P}_{\max }\right)$ for PCHE. $\left(900^{\circ} \mathrm{C}, 1 \mathrm{X} 10^{5}\right.$ hrs)

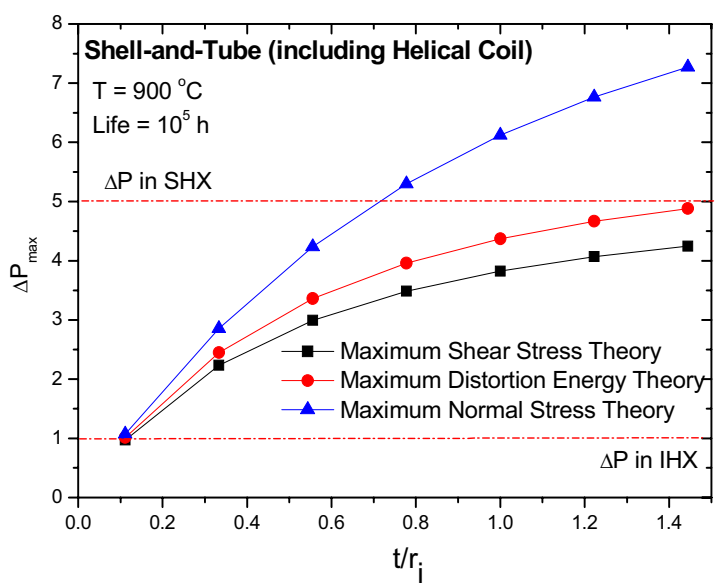

Figure 5. Thickness-to-inner radius ratio $\left(\mathrm{t} / \mathrm{r}_{\mathrm{i}}\right) \mathrm{vs}$. Maximum allowable pressure difference $\left(\Delta \mathrm{P}_{\max }\right)$ for Tubular HXs $\left(900^{\circ} \mathrm{C}\right.$, $\left.1 \mathrm{X} 10^{5} \mathrm{hrs}\right)$.

Table 16 summarizes the required $t / r_{i}$ values estimated by these graphs for a given temperature and lifetime of the IHX for different HX types. This table shows that permanent operation
( $>50$ years) is possible for all temperature ranges for PCHEs. However, Tubular Type HXs requires a little bit larger $t / r_{i}$ value than the reference IHX, but the thickness is still within the possible range for using commercial pipes. For the reference design of tubular HXs, the lifetime is estimated to be $4.1 \times 10^{5}$ hrs (about 47 years) as shown in Table 14.

Table 16. Required thickness-to-inner radius ratio $\left(\mathrm{t} / \mathrm{r}_{\mathrm{i}}\right)$ for IHX.

\begin{tabular}{|c|c|c|}
\hline & \multicolumn{2}{|c|}{$\begin{array}{c}\text { Thickness/Inner Radius } \\
\text { (PCHE/Tubular) }\end{array}$} \\
\hline Temperature & $\mathbf{1 0}^{\mathbf{5}}$ hours & $\mathbf{5 X 1 0 ^ { 5 }}$ hours \\
\hline $750^{\circ} \mathrm{C}$ & $0.0 / 0.0$ & $0.0 / 0.0$ \\
\hline $800^{\circ} \mathrm{C}$ & $0.0 / 0.0$ & $0.0 / 0.05$ \\
\hline $900^{\circ} \mathrm{C}$ & $0.0 / 0.1$ & $0.3 / 0.33$ \\
\hline
\end{tabular}

\section{SUMMARY AND CONCLUSIONS}

As part of the system integration of the VHTR and a hydrogen production plant, the design and configuration of the intermediate heat exchanger have been investigated. This paper included analysis of one stage versus two stage heat exchanger design configurations and simple stress analyses of a printed circuit heat exchanger, helical coil heat exchanger, and shell/tube heat exchanger.

The comparisons of the heat exchanger types showed that the PCHE type offers obvious advantages for its thermal performance, size and compactness. However, it has some difficulties regarding inspections and maintenances. Lack of experience for the long lifetime is another problem. On the other hand, the tubular type HX is ready-to-use technology. Helical coil HXs showed especially great operating records in HTTR application. However it requires too large of a size for highly efficient operations and provides poor thermal performance.

According to the overall comparisons, the two-stage IHX looks better than the single-stage IHX in cost, safety and reliability. Conceptually, two-stage heat exchangers using PCHEs for both the HT and LT unit with a separation temperature of $800{ }^{\circ} \mathrm{C}$ is recommended to be the best option for IHXs. However, to avoid some risks from the lacks of experience in PCHE as IHX, helical coil single-stage helical coil heat exchanger can be another option.

By simple stress analysis, the lifetime and $t / r_{i}$ of the reference HXs has been estimated for the reference thermal designs. As a result, life-time operation ( $>50$ years) is possible for all temperature ranges for both PCHEs and Tubular Type HXs with proper selection of the $t / r_{i}$ value. However, PCHE shows a longer life-time and reliable design than tubular HXs. 


\section{ACKNOWLEDGMENTS}

This work was supported through the U.S. Department of Energy's NGNP-Engineering Program under DOE Idaho Operations Office Contract DE-AC07-99ID13727.

\section{REFERENCES}

[1] Kakac, S.,, Liu, H., Heat Exchangers: Selection, Rating, and Thermal Design, CRC Press, ISBN 0-8493-0902-6, 2002.

[2] Hesselgreaves, J.E., Compact Heat Exchangers, PERGAMON, ISBN 0-08-042839-8, 2001.

[3] Patterson, M, Personal Communication, NGNP Internal Summary, Conceptual Design Studies for NGNP, Project Status Meeting, Feb. 7, 2008.

[4] Hewitt, G.F., Heat Exchanger Design Handbook, Begell House, INC., New York, 2002.

[5] Kern, D.Q., Process Heat Transfer, McGraw-Hill, New York, 1991, 143.

[6] Gezelius, K., Design of Compact Intermediate Heat Exchangers for Gas Cooled Fast Reactors, Degree of Master Dissertation, MIT, 2004.

[7] Heatric ${ }^{\mathrm{TM}}$ Workshop at MIT on $2^{\text {nd }}$ October 2003, Cambridge: MA, 2003.

[8] Bejan., A and Kraus, D., Heat Transfer Hand Book, John Wiley \& Son, ISBN 978-0-471-39015-2, 2003.

[9] Dewson, S., Li, X., Selection Criteria for the High Temperature Reactor Intermediate Heat Exchanger, Proceedings of ICAPP' 05, Seoul, Korea, May 15-19, 2005.

[10] Natesan, K. et al., Preliminary Issues Associated with the Next Generation Nuclear Plant Intermediate Heat Exchanger Design, ANL/EXT-06/46, 2006.

[11] Oh, C.H., Kim, E.S., Sherman, S.R., Vilim, R., Lee, Y.J. and Lee, W.J., HyPEP FY-07 Annual Report: A Hydrogen Production Plant Efficiency Calculation Program, INL/EXT-0713078, 2007.

[12] Aspen Technology, HYSYS process version 3.2, 2006.

[13] Crandal, S.H., Dahl, N.C. and Lardner, T.J., An Introduction to the Mechanics of Solids, Second Edition, McGraw-Hill Book Company, New York, 1972.

[14] Dostal, V., Driscoll, M.J., Hejzlar, P., A Supercritical Carbon Dioxide Cycle for Next Generation Nuclear Reactors, MIT-ANP-TR-100, March 2004.

[15] Collins, J.A., Failure of Materials in Mechanical Design Analysis, Prediction, Prevention, Wiley, 1981. 